\title{
Veblen's Theory of Political Evolution and the Ultimatum Game: A Radical Institutionalist Understanding of 2016 Presidential Election
}

\author{
Avraham Izhar Baranes ${ }^{1}$
}

The 2016 United States presidential election has been seen as a battle of competing, unappealing ideologies: the continuing neoliberalism of Hillary Clinton and the Democratic Party, or the new nationalism of Donald Trump and the Republican Party. With Donald Trump emerging victorious, two questions must be asked. First, what were the underlying issues that made Donald Trump's nationalism appealing to voters, especially those in the "rust belt"? Second, in what way can those opposed to nationalism resist its spread? This paper investigates these issues with respect to what I refer to as Thorstein Veblen's Ultimatum Game. At the end of The Theory of Business Enterprise, Thorstein Veblen (1904) posited that once the "machine system" has become fully engrained in communal life, a capitalist economy has two paths forward: towards socialism, or towards fascism. Putting this into an ultimatum game framework, I view the election of Donald Trump as a rejection of the offer of neoliberalism from Hilary Clinton, rather than an acceptance of the nationalism of Donald Trump. I then argue that the path forward for those on the left is clear: push for a progressive agenda that emphasizes the instrumental and industrial features of the machine system, emphasizing the issues of income inequality, under- and unemployment, and the disappearing social safety net. . [Article copies available for a fee from The Transformative Studies Institute. E-mail address: journal@transformativestudies.org Website: http://www.transformativestudies.org (02018 by The Transformative Studies Institute. All rights reserved.]

KEYWORDS: 2016 Election, Donald Trump, Hillary Clinton, Thorstein Veblen, Ultimatum Game, Neolibarlism, Socialism, Fascism.

\footnotetext{
${ }^{1}$ Avraham Izhar Baranes, Ph.D., is currently a Visiting Assistant Professor of economics at Rollins College. Address correspondence to: Dr. Avraham Izhar Baranes, e-mail: abaranes@rollins.edu.
} 